$\begin{array}{ll} & \text { Etnográfica } \\ \text { etnográfica } & \text { Revista do Centro em Rede de Investigação em }\end{array}$ Antropologia

vol. $26(1) \mid 2022$

Vol. $26(1)$

\title{
Do enfeite à festa: o uso do bordado como narrativa, ação e engajamento em duas festas tradicionais brasileiras
}

From ornament to festivity: using embroidery as narrative, agency and performance in two traditional Brazilian festivals

\section{Thaís Fernanda Salves de Brito}

\section{(2) OpenEdition}

\section{Journals}

\section{Edição electrónica}

URL: https://journals.openedition.org/etnografica/11564

DOI: 10.4000/etnografica. 11564

ISSN: 2182-2891

\section{Editora}

Centro em Rede de Investigação em Antropologia

\section{Edição impressa}

Paginação: 275-298

ISSN: 0873-6561

\section{Refêrencia eletrónica}

Thaís Fernanda Salves de Brito, «Do enfeite à festa: o uso do bordado como narrativa, ação e

engajamento em duas festas tradicionais brasileiras», Etnográfica [Online], vol. 26 (1) | 2022, posto online no dia 25 fevereiro 2022, consultado o 01 julho 2022. URL: http://journals.openedition.org/ etnografica/11564; DOI: https://doi.org/10.4000/etnografica.11564

\section{(ब) $(1) \Theta$}

Etnográfica is licensed under a Creative Commons Attribution-NonCommercial 4.0 International License. 


\section{Do enfeite à festa:}

\section{o uso do bordado como narrativa,}

\section{ação e engajamento em duas festas tradicionais brasileiras}

\section{Thaís Fernanda Salves de Brito}

A cultura dos bordados materializa um saber-fazer que tem atravessado séculos e lugares, revelando modelos de trabalho doméstico, ensinando perspectivas de gênero, atributos morais nas artes da criação e, em certos momentos, caminhos para ação política. Bordar é uma ornamentação nos tecidos a partir de linhas que trazem volumetria e cor, cujos riscos partem de um repertório amplo e criativo de técnicas e de usos que narram histórias, memórias, conhecimentos. Como parte deste extenso repertório, há uma modalidade específica de bordado: o richelieu. Este bordado é feito por uma espécie de jogo entre a volumetria das linhas sobre o tecido e dos recortes feitos nos tecidos, assemelhando-os às rendas. $\mathrm{O}$ bordado richelieu compõe uma longa tradição na transmissão do saber-fazer e nos modos de uso das peças e, para a cultura do bordado, assume papel de elegância, tradição e sofisticação. Contudo, um olhar mais atento pode nos conduzir a outras potências (inclusive, podem transcender o seu caráter ornamental). A presente investigação parte de um olhar comparativo para duas festas tradicionais do nordeste brasileiro, nas quais o bordado richelieu assume um lugar de destaque: a festa de Sant'Anna (Caicó, RN) e a festa de Nossa Senhora da Purificação (Santo Amaro, BA). Aparentemente inofensivos, no contexto dessas festas, esses bordados transpõem a noção de souvenirs, enfeites para a casa ou indumentária, conduzindo discursos, narrativas e posicionamentos políticos imprevisíveis.

PALAVRAS-CHAVE: bordado richelieu, festa, política, Santo Amaro, Caicó.

From ornament to festivity: using embroidery as narrative, agency and performance in two traditional Brazilian festivals - The culture of embroidery materializes a know-how that has crossed centuries and places, revealing models of domestic work, teaching gender perspectives, moral attributes in the arts of creation and, at certain moments, a political action approach. Embroidery is an ornamentation on textiles from threads that bring volumetry and colour, whose risks are taken from a wide and creative repertoire of techniques and uses that narrate stories, memories and knowledge. As part of this varied repertoire, there is a specific type of embroidery: richelieu. It is created through a sort of fusion between the volumetry of the threads on the textile and the cut-outs made in the fabric, resembling lace. Richelieu embroidery has a long tradition in the expertise transmission as well as in the use of the objects and, for the embroidery culture, it represents elegance, tradition and sophistication. However, a closer look can lead us to other potencies (transcending its ornamental character). The present investigation is based on a comparative study between two traditional festivals in northeastern Brazil in which 


\begin{abstract}
richelieu embroidery takes a prominent place: the Festa de Sant'Anna (Caicó, RN) and the Festa de Nossa Senhora da Purificação (Santo Amaro, BA). Seemingly innocent, in the context of these festivals these embroideries transcend the notion of souvenirs, ornaments for the household or costume, leading to unpredictable discourses, narratives and political positions.
\end{abstract}

KEYWORDS: richelieu embroidery, festival, politics, Santo Amaro, Caicó.

BRITO, Thaís (thaisbrito@ufrb.edu.br) - Universidade Federal do Recôncavo da Bahia, PPGAP/Mesclas/Cecult e Universidade de São Paulo, Coletivo Asa/FFLCH, Brasil.

\title{
INTRODUÇÃO: É O BORDADO UM VEÍCULO DE POLÍTICA?
}

Bordados têm atravessado séculos revelando modelos de trabalho doméstico, ensinando perspectivas de gênero e atributos morais na arte do fazer criativo. Como parte do universo da cultura material, os bordados apontam sistemas simbólicos e podem ser entendidos como um resultado visível de técnicas e de práticas sociais, comunicando-se com padrões e perspectivas mais amplas. Em constante circulação e diáspora, eles funcionam como uma espécie de linguagem que reúne expressão verbal - por meio de narrativas sobre o bordar e sobre processos de ensino - e linguagem não verbal através de temas, técnicas, modos de se apresentar e de se usar, e que podem transcender a ornamentação. ${ }^{1}$ Observar o transcender dos bordados é o objetivo deste artigo.

O nordeste brasileiro é farto em produção e circulação de bordados. Uma das ações do processo colonial foi ensinar mulheres a bordar. Inclusive a modalidade de bordado richelieu encarnou uma forma de "civilizar" a população feminina brasileira ao papel que lhes era esperado, como veremos adiante. O bordado richelieu é parte do grupo de técnicas que se convencionou como whitework. Com função exclusivamente ornamental, simbolizam elegância, valorizam um modelo de beleza e estão associados aos padrões tradicionais de etiqueta europeia.

Por princípio, bordado richelieu não arrola formas de ação política e está relacionado com as classes altas. Entretanto, seja como símbolo de um lugar, um produto cultural ou parte de uma indumentária sagrada, testemunhei esta modalidade de bordado tendo o seu sentido (colonial) proposto capturado e

1 Considerar os bordados como possibilidade de expressão política é resultado de reflexões travadas durante o período de estágio pós-doutoral, junto à Universidade de São Paulo, com supervisão da Prof. Dra. Fernanda Arêas Peixoto, a quem agradeço as muitas contribuições nesta discussão. 
tornando-se o mote para performances de mediação política em contextos de festas populares em duas cidades do nordeste brasileiro.

As festas permitem múltiplas leituras da vida social, outras linguagens, rupturas da ordem, e podem funcionar como alternativas de mediação nas rígidas estruturas sociais (Amaral 1998). Seguindo esta lógica, é possível considerar que os bordados, em contexto de exceção, prolongam as características festivas uma vez que são parte da materialidade dos eventos. Ao saírem às ruas, como veremos adiante, o uso esperado é invertido, relativizando, deste modo, a ordem e o seu sentido usual, por consequência manifestando-se em materialidade desobediente.

Certas lutas políticas levadas a cabo pelas mulheres fizeram uso radical dos bordados, o que nos ajuda a observar a materialidade desobediente dos bordados. Ainda que permaneçam as técnicas de bordar, os estilos e, até mesmo, a circulação e o uso das peças, esta prática criativa, ao assumir perspectivas políticas insurgentes, ressignifica os bordados em contexto, alterando-se o seu propósito usual.

O "craftivismo", 2 por exemplo, é um movimento ativista, anticapitalista, feminista e ambiental que tem se tornado popular nas últimas décadas. Parte-se da concepção de que a produção artesanal pode ser uma "voz" potente, impactando situações de crises, por meio da arte e do protesto gentil, o que em nada significa fraqueza, neutralidade ou um modelo não assertivo de insurgência (Corbett 2017). Craftivistas produzem coisas, prioritariamente têxteis, fazendo amplo uso da produção de bordados pelas mensagens de ativismo político. Inclusive, os riscos que orientam os bordados ligados ao craftivismo incluem palavras, textos ou figurações de protesto.

Tradicionalmente, a cultura do bordado pede sempre criatividade e renovação, ainda que se mantenham os processos de feitura. Para isso, os riscos (e, com isso, os temas) são sempre atualizados e, como observa Peixoto, o risco do bordado é uma forma de arriscar-se (Peixoto 2020). No caso do craftivismo é interessante notar que o bordado cria, em si, o risco da promoção de atos de resistência, ao mesmo tempo que amplia a manutenção da técnica, da arte da criação e fomenta o desenvolvimento de artesãs. ${ }^{3}$ Ou seja, correr este risco significa compreender que a prática artesanal pode servir, também, como uma tática subversiva, um tipo de clamor e uma espécie de testamento de perseverança que parte de um aprendizado transformacional, pessoal e político.

A ornamentação de tecidos aponta para um aprendizado secular, relacionado às tarefas femininas, ao universo da casa e à disciplina do corpo. Contudo, ainda que pareça preso à realidade doméstica, não é recente o uso dos

2 Neologismo, a partir do inglês craftvism, termo cunhado por Betsy Greer em 2003.

3 Considerando a majoritária presença das mulheres na produção dos bordados, priorizar-se-á o uso feminino da palavra artesã. 
bordados como veículo de exercício político. Corbett (op. cit.) nos lembra que durante a ditadura militar do Chile, entre 1973 e 1990, as Arpilleras ${ }^{4}$ narravam em bordados aquele período histórico marcado por sequestros, execuções, prisões, torturas, desaparecimentos de maridos, filhos, pais, amigos... A técnica do bordado tradicional chileno consiste, basicamente, em elaborar uma espécie de manta, colorida e vibrante, com figuras e ornamentos aplicados, inclusão de ornamentos, variações de pontos de bordados e pequenos textos - também bordados - que descrevem a vida cotidiana e o mundo rural sobre um tecido rústico, como a estopa. Porém, durante a ditadura de Pinochet, as peças passaram a incluir novos temas e apliques: os fragmentos de roupas de perseguidos políticos se transformaram em "ornamentos" e encarnaram a representação do assombro.

As mantas que foram bordadas pelas mulheres em cárcere, apesar dos difíceis temas narrados, incluíam ainda uma função terapêutica: os bordados exigiam concentração, o que trazia certa pausa no sofrimento. Distribuídas secretamente, as peças geraram engajamento popular na denúncia de violação de direitos humanos junto das comunidades internacionais, ademais, vender esses bordados em circuitos de comércio justo serviu como geração de trabalho e renda para famílias que se encontravam em situações extremas. Enfim, esta arte tão delicadamente desobediente $\mathrm{e}$ subversiva se revelou um exemplo de "arte solidária" em contexto de resistência comunitária (Adams 2013) e uma arma con-

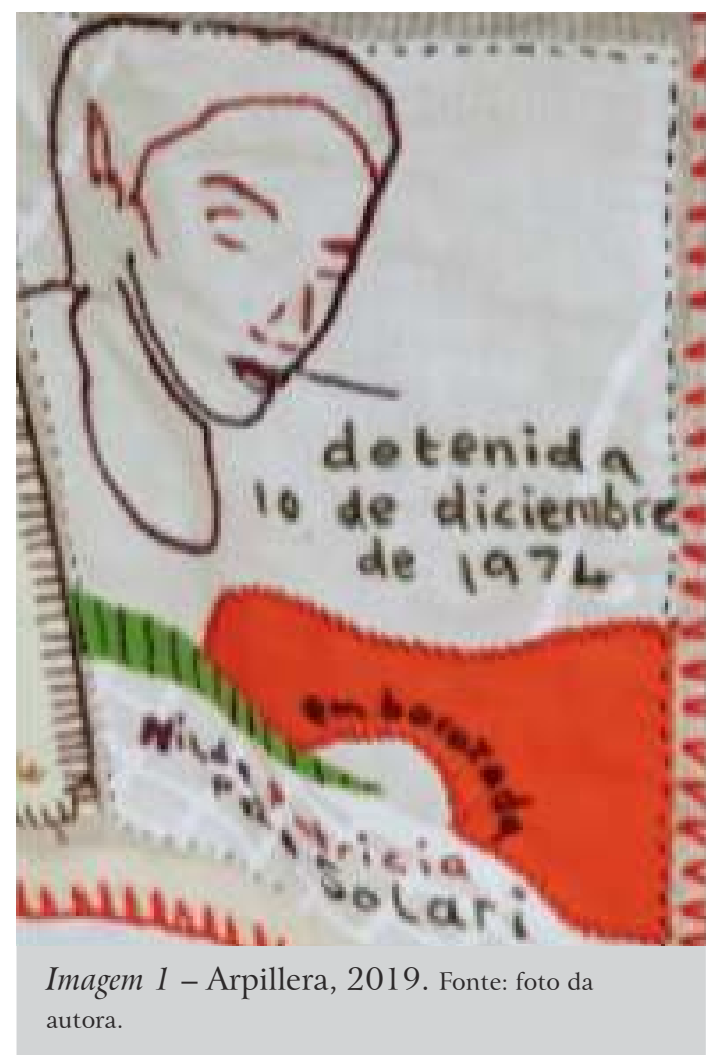
tra os tempos sombrios. Flood e

4 Sugiro o filme Crafting Resistance, dirigido por Carmen Luz Parot e Gloria Miqueles, produzido por Jasmine Gideon, 2018, 25 min. Disponível em < https://vimeo.com/26359279l > (última consulta em janeiro de 2022). 
Grindon (2014), ao olhar para "objetos desobedientes" 5 nos quais incluem as arpilleiras e as craftivistas, notam que estes bordados têm:

“[...] poder de seduzir o público. As pessoas são atraídas pela extrema habilidade e pelo tempo necessário para se criar uma peça [...] [e] o espectador pode ser emocional e intelectualmente desafiado. Há uma expectativa de que o trabalho artesanal seja gentil, decorativo e seguro - mas uma vez tendo o público engajado, estamos em uma zona ideal para explorar opiniões radicais e controversas." (Flood e Grindon 2014: 13) ${ }^{6}$

Ao seguir a pista de que os bordados podem ir além de sua função ornamental e que permitem explorar controvérsias, encontraremos arabescos, frases de ordem e a constante flor violeta nas peças das sufragistas inglesas no início do século XX (Corbett 2017). A violeta é uma flor que se propaga fácil e horizontalmente, por sementes e como rizomas. Por isso, esta florzinha foi escolhida como símbolo da luta sufragista, sendo bordada muitas vezes. Exemplos destes artefatos, produzidos em condição de violência e de ruptura social, foram encontrados na prisão Holloway. Os itens tinham usos variados, ornamentados pelas flores bordadas em estilo art déco, com nomes das prisioneiras, suas assinaturas, aplicação de fotos e a inscrição "Votes for WOMEN" ou "WorKED IN HollowaY" (Jones 2020).

Ao analisar essa narrativa material, Jones observou que os exemplares tocam, ainda que de modo velado, a forma como aquelas mulheres exerciam a política e viviam a detenção. Bordar memórias de cárcere e de luta foi uma forma de manterem-se livres, ligadas e em ação, através de uma espécie de linguagem discreta, tal qual as arpilleiras. Jones chama este movimento de "thread act", algo que poderia ser traduzido como "ato em linha"; "a linha como um material entrelaçado e em ação com o corpo relacional e pensante das sufragistas" (Jones 2020: 5). Bordar conecta uma bordadeira a outra e pode, inclusive, transpor gerações.

Gardner (2016) percorreu o uso anterior desses "objetos políticos" e observou que os bordados abolicionistas já haviam introduzido a política como parte da vida doméstica. Mulheres, proibidas de emitir sua opinião, bordavam protetores de bules com cenas onde escravos eram açoitados, assim como pequenas bolsas de passeio ou toalhas com homens acorrentados. ${ }^{7}$ Edward

5 Entre julho de 2014 e fevereiro de 2015, o Museu Victoria \& Albert, em Londres, apresentou a exposição Disobedient Objects, dedicada à agência dos objetos em situações de protesto e de ativismo político, pós 1970. A curadoria incluiu elementos como faixas, máscaras, têxteis, robôs, barricadas, infláveis, considerando ainda o ponto de vista da arte e do design.

6 Tradução da autora.

7 Algumas instituições guardam estes exemplares abolicionistas e disponibilizam imagens online: Museum of London, Victoria \& Albert Museum, British Museum, Brooklyn Museum, Firestone Library. 
Cornelius Osborne (1830) publicou em Inglaterra um pequeno poema antiescravista, dirigido ao público infantil, "Zante the Negro" que, anos depois, inspirou Maria Wilds (1848) a bordar, em ponto-cruz, a imagem símbolo da British Foreign Anti-Slavery Society. O bordado continha em seu centro um escravo jovem, ajoelhado, com mãos acorrentadas e em posição de oração e clemência, implorando por salvação, emancipação e liberdade. Acima da imagem, o poema "[D]rag[ge]d from my native home/ $[\mathrm{B}] \mathrm{y}$ a cruel white mans hand/ $[\mathrm{N}]$ o more to see my native home/ $[\mathrm{N}]$ o more to see my native land". ${ }^{8}$ $\mathrm{O}$ bordado se tornou popular entre os simpatizantes antiescravagistas, fartamente copiado e utilizado em adornos. Mais do que isso: o recado estava dado, a narrativa dos bordados rompeu com o silêncio imposto.

A abertura desta reflexão buscou sensibilizar o leitor para romper o estigma do bordado como algo fútil, supérfluo e restrito à ocupação de mulheres de elite ou como uma espécie de restrição feminina à vida pública. Para isso, partiu-se da produção e da circulação de bordados feitos com um fim político específico. Mas será que os bordados são políticos apenas quando são feitos com este propósito? É possível um uso político e performático das formas de bordar e das bordadeiras em circunstâncias públicas? Quando os bordados migram de mãos, como, por exemplo, quando escapam das mãos das senhoras de escravo e vão para os terreiros de Candomblé vestir os orixás, eles produzem ação política? É possível uma indumentária sagrada fazer política?

A seguir apresentarei duas festas populares do nordeste brasileiro. Vale lembrar que, mais do que mera "fruição, divertimento ou 'válvula de escape' pelas tensões acumuladas na vida cotidiana" (Amaral 1998: 5), as festas populares revelam crises latentes, perspectivas sobre a rotina, formas de exercer a cidadania e de fazer política. Uma característica interessante é que as duas festas tangenciam representações femininas na devoção, pelos mitos e ritos, e também pela presença contínua do bordado richelieu, usado em profusão na indumentária, como artefato de decoração ou na comercialização de produtos regionais.

Realizado a partir de duas etnografias, a primeira em 2007 e a outra em 2019 , este artigo apresenta uma análise comparada do uso do bordado richelieu em duas festas populares e tradicionais do Nordeste Brasileiro: Festa de Sant'Anna e Festa de Nossa Senhora da Purificação. São festas cuja importância transcende suas cidades e integram o calendário cultural dos seus estados. Este artigo se divide em quatro partes, intituladas "O bordado richelieu", "Dois jeitos de fazer política: bordado e festa" e "Considerações finais", somadas a esta introdução.

8 "Arrastado do meu país natal/ Pelas mãos de um homem branco cruel/ Nunca mais verei minha casa/ Nunca mais verei minha terra" (tradução da autora). 


\section{O BORDADO RICHELIEU}

O bordado richelieu deriva de uma longa tradição. É encontrado em dezenas de países e realizado a partir de uma organização de pontos de bordado: cheio, aberto, ponto reverso (como haste e ponto atrás) e caseado, em seções reunidas, urdidas e recortadas que tornam o tecido vazado, com aspecto de renda. Alterna formas em abstração, como arabescos, círculos e semicírculos e temas figurativos ou principalmente flores e folhas. Ainda que a execução dos pontos seja um tanto simples, sua composição e processo são complexos e detalhados, abrangendo desde a escolha das matérias-primas, o uso destinado à peça, os motivos e a circulação das peças.

As principais etapas para fazer o bordado são: as escolhas dos materiais (tecido, linhas, aplicações); o corte do tecido; a elaboração do risco e a transferência do desenho para o tecido; o ato de bordar (e/ou de cobrir), cortar e desfiar as partes do bordado que são necessárias para criar o efeito vazado na peça; a lavagem e engoma; o acabamento, acondicionamento e distribuição. Pode ser feito à mão ou à máquina (mais popular no Brasil após a popularização das máquinas de bordar). O sucesso do bordado da Madeira popularizou o uso de cores no richelieu, a partir do século XX. ${ }^{9}$

Surgido, possivelmente, na Itália renascentista, com freiras que produziam tecidos finos para o uso eclesiástico, este bordado, associado à realeza e à

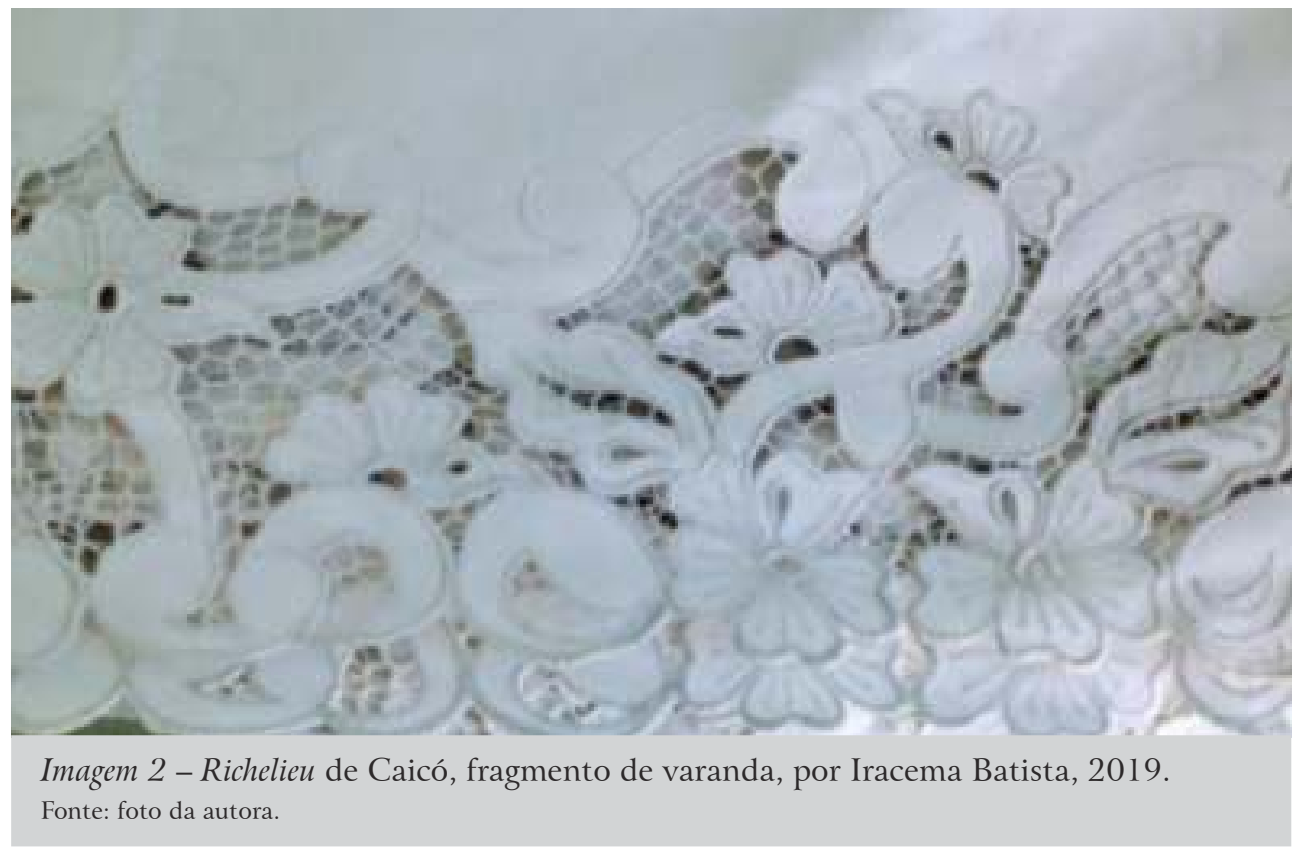

9 Para entender este bordado, sua estética, história, impactos econômicos e sociais, ver Klut (2017). 


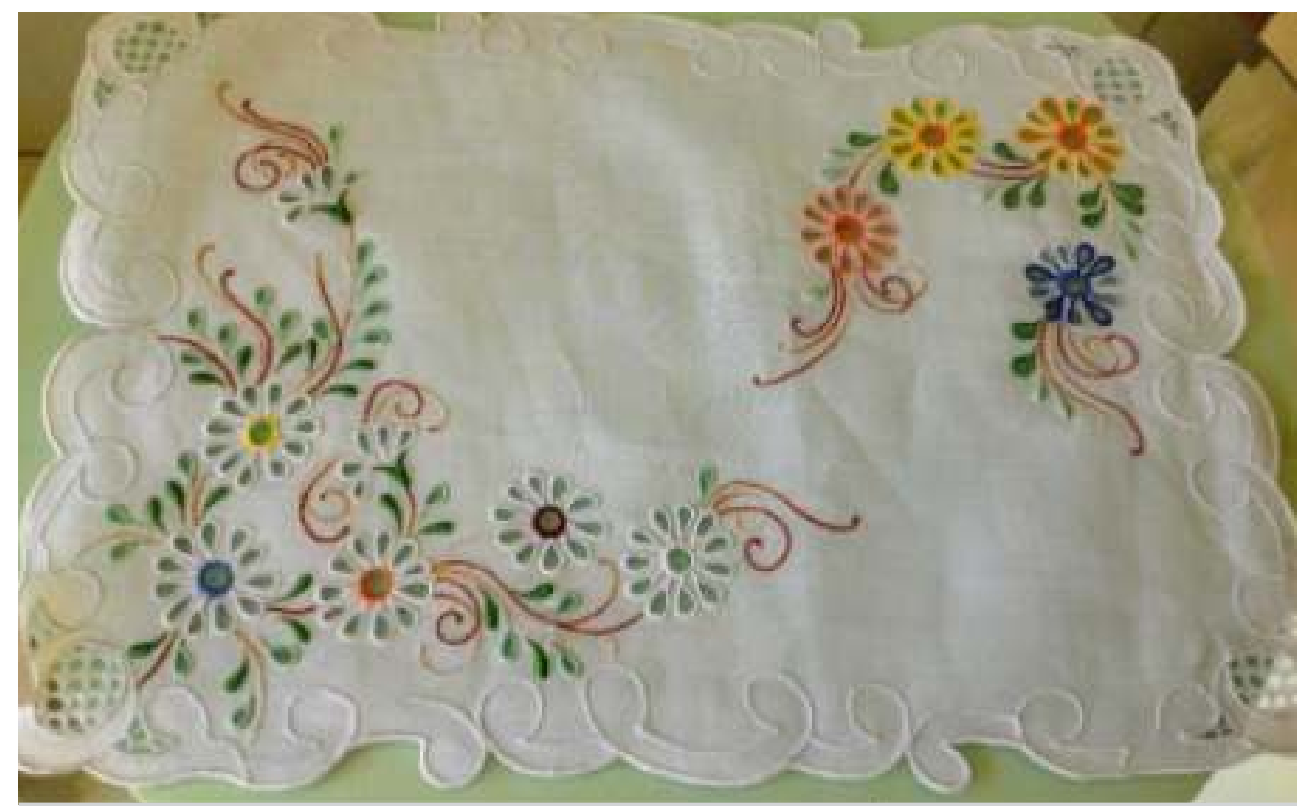

Imagem 3 - Toalha de bandeja em richelieu colorido, por Iracema Batista, 2007. Fonte: foto da autora.

nobreza, passou a ser realizado por especialistas que faziam enxovais e demais adereços para a casa. Seu prestígio era tal que as peças eram ofertadas como presentes de elevada posição social. Além da demonstração pública do cuidado com a casa, o richelieu se tornou parte da educação feminina, forma de expressão estética e possibilidade de trabalho para as mulheres não privilegiadas. Houck (2013) relembra que:

"Pela história, rainhas e damas da corte, meninas, servas e mulheres da Igreja, executaram seu bordado branco em uma variedade de peças e por uma variedade de razões. As meninas, em muitos países e de múltiplas classes sociais, eram consideradas não educadas se não tivessem seus belos cadernos de amostra quando chegassem aos dez anos de idade. As empregadas eram frequentemente contratadas devido ao seu conhecimento com as agulhas. Uma empregada doméstica provavelmente se sentiria com mais sorte se ficasse cega de tanto bordar os roupões de sua patroa do que em esfregar o chão. Rainhas e damas, além da necessidade em ocupar o seu tempo ocioso, provavelmente consideravam seu bordado como principal meio de expressão, como Mary Rainha da Escócia." ${ }^{10}$ (Houck 2013: 3) 
Foi na corte de Luís XV que este saber-fazer se disseminou pela influência do cardeal e ministro Armand Duplessis, o conde Richelieu. Ainda não se sabe, ao certo, quando este tipo de bordado aportou em terras brasileiras. É possível que tenha vindo com a transferência da corte portuguesa para o Brasil, em 1808, cuja presença imprimiu um "choque cultural" sem precedentes (Schwarcz 2018 [1998]), colocando a moda e a invenção da etiqueta em pauta da vida dos brasileiros. Inspiradas nos modelos franceses em voga, o uso dos bordados e das rendas, seja na indumentária ou nos ornamentos domésticos, se tornou um desejo.

O richelieu, desde então, representou uma distinção para a elite, relacionado com situações privilegiadas e funções decorativas. Como ocorreu em outros locais, os bordados se disseminaram, inclusive como um fundamento para a educação feminina nesta nação que buscava parecer moderna, racional (apesar da escravatura) e produtiva. ${ }^{11}$

Os labores das mulheres de elite incluíam bordados, rendas e tecelagens. Animados pela rigorosa formação moral (e a chegada dos conventos), vieram se somar à ênfase na confecção de enxovais como forma de preparação para o papel a ser desempenhado no lar. Bordar era parte das responsabilidades do cotidiano e da gestão da casa (Carvalho 2008; Brito 2010).

Durand (2006), ao refletir sobre outro contexto - o das bordadeiras do Minho, em Portugal - e pensando sobre as relações de gênero que impactam a produção do "lenço dos namorados", observa que a partir do século XIX, até pelo menos metade do século XX, a bordadeira e a costureira encarnavam a representação da mulher virtuosa e da trabalhadora que nutriam valores como poupança, engenhosidade, boa aparência, dignidade, respeito à ordem, disciplina e precisão do corpo para executar seu ofício, ainda que, no geral, essas mulheres trabalhassem de modo invisível. Carvalho (2008), refletindo sobre a realidade da casa brasileira no século XIX, traz outra pista que, quiçá, nos aproxime ainda mais da difusão deste saber-fazer e adesão das mulheres brasileiras ao bordado: "uma forma de marcar a distância da dona de casa dos trabalhos braçais sujos, pesados e repetitivos considerados como atividades degradantes" (Carvalho 2008: 76).

Fato é que as mulheres da elite não davam conta de bordar o que desejavam. Para isso, uma multidão de escravas e de mulheres pobres serviam para cozer, bordar, lavar, engomar e cuidar das peças com zelo, alternando as pesadas

11 Schwarcz, ao tratar da organização diária da educação do jovem príncipe Pedro e de suas irmãs Francisca e Januária, demonstra a disposição à criação de um jovem país afeito à ciência, à disciplina e ao conhecimento. Assim, apresenta, entre outros materiais, a aquarela que Adolphe D'Hastrel produziu em 1839. Intitulada "D. Pedro II estudando junto a suas irmãs Januária e Francisca", vemos que "enquanto D. Pedro desenha um busto esculpido, suas duas irmãs interrompem a lição de bordado para observá-lo" (Schwarcz 2018 [1998]: 130). Agradeço imensamente as conversas e as reflexões sobre esta imagem estimuladas por Maria Teresa Perdigão de Oliveira Rito. 
tarefas de casas, lavouras e comércios dos senhores. Após a abolição da escravidão, esses labores seguiram como possibilidade de trabalho e renda para pobres e libertas. As mulheres do semiárido, onde se localiza Caicó, têm enfrentado severas crises ambientais, econômicas e de êxodo rural, principalmente masculino, bordando diuturnamente enxovais para famílias abastadas e souvenirs para turistas das praias nordestinas (Brito 2016). No caso do Recôncavo da Bahia, os bordados - e a manutenção deles - além do aspecto disciplinador e educacional, permitiram que as mulheres encontrassem um trabalho menos pesado do que o labor da lavoura e, hoje, seguem exercendo papel essencial ainda que não sejam maciçamente produzidos na cidade.

\section{DOIS JEITOS DE FAZER POLÍTICA: BORDADO E FESTA}

As bordadeiras de Caicó ${ }^{12}$ costumam dizer que os bordados chegaram com os movimentos de ocupação do espaço seridoense para criação dos currais de gado, formação de pequenas lavouras, e como parte das atividades ligadas à cotonicultura na região. ${ }^{13}$ Esta é uma narrativa popular, mas não única: há a presença da educação católica pelas freiras e a inspiração com o bordado madeirense (Brito 2019). Foi, aproximadamente, nos últimos 60 anos, que o bordado richelieu se tornou trabalho naquela região e difundiu no Rio Grande do Norte a cidade de Caicó como a "terra do bordado". ${ }^{14}$ Os bordados produzidos na cidade atendem ao mercado interno, ao circuito do luxo das grandes capitais, principalmente o comércio de enxovais finos e, além disso, para o mercado de souvenirs, caracterizados pelas pequenas peças, com qualidade e valor inferior, vendidas nas cidades litorâneas do nordeste brasileiro. Todavia, é somente na festa de Sant'Ana que vemos bordados em profusão pela cidade. Ali, eles saem das casas e das poucas lojas que se dedicam à comercialização das peças e se tornam uma personagem da festa. É por meio deles que as bordadeiras se apresentam com sua leitura específica do lugar, das suas relações e das lógicas da política.

12 A cidade de Caicó se localiza na região do Seridó Ocidental, no estado do Rio Grande do Norte. Dista cerca de $282 \mathrm{~km}$ de Natal, capital do Estado. O último censo, em 2010, registrou um população de 62.709 pessoas (IBGE 2010).

13 O desenvolvimento da cotonicultura estimulou a produção de redes de dormir, e os bordados serviam como adorno. São comuns as narrativas relacionando a popularização dos bordados ao trabalho feminino no fiar do algodão, tecer e ornamentar as redes (Cascudo 2003).

14 Dois fatores foram essenciais: a popularização das máquinas de bordar e a criação da Escola Profissional Julia Medeiros (Brito 2016) que, desde 1975, oferta cursos profissionalizantes de técnicas de bordado, corte e costura, crochê, pintura, flores artificiais, culinária. Esta escola surgiu após um primeiro grupo de bordadeiras, décadas antes, ampliar o mercado consumidor e precisar fomentar o ofício (Araújo 2013). Entretanto, destaco que técnicas, formas de bordar e de ser bordadeira são prioritariamente apreendidas nos circuitos coletivos de família, vizinhança e laços de amizade (Brito 2010, 2016). 
Santo Amaro, ${ }^{15}$ outro lugar a que esta investigação nos leva, não é um lugar de produção de bordados, diferentemente de Caicó. Contudo, eles têm presença intensa na vida da cidade e não estão restritos ao universo doméstico ou à moda, algo que nos seria mais comum. Torres (2004 [1950]) e, depois, Lody (2019) remetem a popularidade do richelieu ao hábito colonial das senhoras vestirem suas escravas com luxo como forma de distinção, principalmente suas escravas de ganho (mulheres que trabalhavam nas ruas vendendo de hortaliças a joias e prestando serviços vários). O que nos chama a atenção, no entanto, é que este bordado rompeu seu destino de bem vestir a elite com suas perversas lógicas coloniais, e ressignificou o seu uso como parte da estética do Candomblé: o richelieu compõe a indumentária sagrada de filhos e filhas de santo.

\section{O uso do bordado na festa de Sant'Anna, em Caicó, RN}

Caicó fica no interior do Rio Grande do Norte, na região do Seridó. Ainda que, usualmente, relacionada às situações de difícil sobrevivência pelas suas características naturais, é uma cidade de bordados férteis, alegres e precisos. O bordado richelieu é característico da produção local, feito com maestria, seja branco ou colorido.

É para a festa de Sant'Ana, no mês de julho, que os bordados percorrem os mais variados espaços da cidade. Ramos Filho (2015) conta que o culto à avó de Jesus, apesar de não prescrito nas escrituras cristãs, remete às sociedades agrícolas - como Caicó - e revela uma apropriação católica dos rituais de semeadura, a partir de correlações simbólicas com o feminino: gestar, gerar, alimentar.

Há mais de 270 anos, entre os dias 19 e 29 de julho, Caicó celebra a avó de Jesus e seus milagres na região por meio da comida farta, dos bailes, do jeito de cuidar da casa e de se enfeitar. Este é o momento de se contar muitas histórias que vão das narrativas de assombração às memórias da lida no campo. Nestes dias, a cidade guarda uma vida intensa, constituindo "um tempo e um espaço de sociabilidade no qual o sagrado e o profano se entrelaçam na construção de uma identidade coletiva" (IPHAN 2010: 70). Recordar e reunir os filhos da terra, "relembrar a história da cidade, reavivar laços de solidariedade fundados na família ampliada, reafirmar valores cristãos e acionar registros específicos da cultura seridoense" (idem) permitem que os marcos de sociabilidade sejam refeitos em pactos identitários. Para Cavignac et al. (2010), são eleitos:

15 Também conhecida como Santo Amaro da Purificação, localiza-se na região do Recôncavo, a $71 \mathrm{~km}$ de Salvador, capital da Bahia. Em 2010, a população da cidade era de 57.800 pessoas. Entre o século XVII e final do XIX, a cidade assumiu um papel importante do projeto colonial pela "produção de cana-de-açúcar e seus derivados [...], produção de fumo, todos para exportação e de produtos para a subsistência da própria população da região" (Marengo 2016: 142). 
“[...] elementos representativos da 'sua' tradição como o artesanato de bordados, as comidas 'típicas' ou as melodias tocadas pelas bandas de música durante as alvoradas. Assim, a festa de Sant'Ana de Caicó se projeta como a expressão por excelência da cultura e da identidade do Seridó.” (Cavignac et al. 2010: 68).

Cerca de 100.000 fiéis participam anualmente desta festa em que os bordados aparecem em todos os lugares. $\mathrm{Na}$ "festa, o bordado é publicizado. Ele sai da casa da bordadeira e vai para a rua. Da rua, parte para outras casas, levando sempre consigo a bordadeira que os fez, sua história, seus saberes." (Brito 2010 : 241 ) Costuma ser uma honra para uma bordadeira executar as indumentárias litúrgicas que acompanham novenas e missas. Participar da procissão da missa solene, com trajes brancos e bordados, é um desejo dos fiéis que se programam para investir em roupas preparadas com antecedência. Bordados enfeitam os lares desde os batentes das janelas e as visitas são recebidas com enxovais elegantes, peças herdadas (e cuidadas por gerações) ou encomendadas para este.

Há mais de dez anos o complexo turístico Ilha de Sant'Ana ampliou o território da festa. É um espaço amplo, com estrutura de bares e restaurantes, anfiteatro, ginásio poliesportivo e palcos para shows, onde se desfruta da gastronomia do Seridó, de músicas e parque de diversões. Ali ocorre a Feira de Artesanato dos Municípios do Seridó (Famuse) e cabe ao Comitê Regional das Associações e Cooperativas do Artesanato Seridoense (Cracas), em parceria com o Serviço Brasileiro de Apoio às Micro e Pequenas Empresas (Sebrae), organizar a disposição de mais de 100 stands, setorizando artesãos e produtores de produtos regionais, além de buscar financiamentos, elaborar o conceito do espaço e promover a divulgação da feira. Construir esta experiência, valorizando aspectos regionais e driblando inúmeras dificuldades, é um processo árduo e demanda esforços individuais, enfrentamentos e ajustes políticos. Tarefa realizada, principalmente, por Arlete Silva, presidente do Cracas.

Diferentemente de outras feiras de caráter comercial e impessoal, nas quais essas bordadeiras costumam participar, a Famuse aponta para outros sentidos. É um lugar de encontro: caicoenses (os que vivem na região e os “ausentes"), ${ }^{16}$ turistas, políticos e muitas bordadeiras estão engajados na mesma experiência. Dentre os produtos comercializados, bordados são destaque, assim como são as suas bordadeiras. Nem todas as bordadeiras vão à Famuse para expor suas peças. Muitas vão rever companheiras, descobrir se o seu bordado é competitivo (e competir), atualizar-se sobre os valores cobrados, ver e ouvir sobre novidades que as beneficiem. Mais do que um espaço para vender bordados em lugar e circunstância privilegiados, ali é um espaço de ajuntamento, discussão, cooperação, competição, distinção e união. 
Aliás, este é um espaço de performances. O Estado, por meio de prefeituras e do Sebrae, repete elogios e promessas, apresenta projetos e conceitos que são normalmente vistos com desconfiança. Arlete Silva é quem profere o discurso de abertura, conduz a homenagem ao artesão do ano e as demais falas. Em 2007, em discurso vibrante afirmou: "bordadeiras são as guardiãs de um saber e sem incentivo não há como manter o bordado". Proclamou que "o bordado de Caicó é o cartão postal da região", "é uma herança", "aquilo que a cidade guarda de mais bonito". Ciente de seu público e diante da presença de instâncias de governo e de fomento do artesanato, essa liderança falava, simultaneamente, para as instituições que costumam objetivar o bordado e o ofício, transformando-os em produtos de identidade regional para suas plataformas e interesses, para as bordadeiras que precisam manter-se cientes de seu papel como produtoras e cidadãs, valorizando a parceria com as associações.

Nesta Famuse, concorrendo com as falas oficiais, uma performance persegue minha memória. Uma das bordadeiras aceitou o convite de Arlete para elaborar uma cena, na qual ela e sua família bordavam. Assim, cinco mulheres - incluindo duas irmãs, sua mãe (que receberia uma comenda em homenagem à dedicação ao bordado) e sua filha mais nova, na época com nove anos, ficavam sentadas em uma grande mesa, com alguns trabalhos expostos. Sobre a mesa, bordados apresentando técnicas, peças em processo de feitura junto aos bastidores e, no final, uma máquina Singer de pedal, objeto essencial em Caicó para a produção do richelieu.

A cena era muito bonita e traduzia uma performance interessante sobre o ofício de bordar, reafirmando o aspecto geracional e o aprendizado familiar. A bordadeira parecia muito feliz, dizia que "assim como a mãe [dela] as ensinou, agora [ela] ensinava para suas filhas". Em meio à agitação e conversando sobre a feira, os bordados, os órgãos do Estado e o papel da associação, uma senhora se aproximou. Com muita convicção e em tom provocativo, repetiu uma frase recorrente na cidade, mas que, naquele contexto, soou impactante: "Só assim o bordado daqui sobrevive! É assim que sempre se fez e se fará! Só quando a mãe ensina a filha é que se tem um bordado de verdade. A geração é o mais importante!" Todas concordaram. ${ }^{17}$

Naquele momento, olhando para a família e atenta às palavras emocionadas, meu foco se dirigiu para a questão geracional. No entanto, considerando as cenas desenvolvidas - discursos oficiais e família bordando - literalmente lado a lado, percebo que não se tratava apenas da valorização do ensino geracional, mas

17 As falas proferidas por ocasião deste evento foram registradas em caderno de campo, em julho de 2007. Infelizmente, não tenho nenhuma foto da performance, talvez a ausência de registro se justifique pelo fato de não ter entendido, naquele momento, o quanto essa cena repercutiria em minhas reflexões. Entre a escrita atual e a pesquisa há um longo período, por isso preservei, aqui, o nome das pessoas envolvidas, exceto aquelas que remetem às falas públicas, como as da representante do Cracas. Na ocasião, todas estavam cientes da realização da investigação para o doutorado. 
revelava crítica às políticas públicas que não chegavam na realidade da produção de bordados em Caicó. A existência do richelieu na performance familiar era apenas fruto do esforço, do trabalho e do investimento pessoal em ensinar gerações de mulheres a bordar, o que em nada significava adesão às políticas públicas.

A fala impactante da presidenta do Cracas, um tanto alinhada aos discursos oficiais, não se restringe à cena de abertura da feira. Em 2019, o convite para a Famuse trouxe uma imagem potente e que ilustra não apenas o discurso do comitê mas, também, este papel simbólico, retórico e social que bordados e bordadeiras assumem na região. A foto que ilustra o convite retrata uma imagem reiterada em ilustrações, na qual o bordado assume ar romântico. A caatinga é o cenário, mas ela está verde, como se houvesse chuva farta. Ao fundo, sugere-se a serra do Seridó. Em segundo plano, vemos a vegetação típica: um belo mandacaru, florido. Em frente ao arbusto, em primeiro plano, uma bordadeira jovem, com expressão tranquila e descansada, sentada à máquina e bordando uma peça de richelieu colorido já engomada. A foto em nada corresponde às queixas quanto às dezenas de horas que as bordadeiras se dedicam a uma única peça ou à sensação de abandono das políticas públicas. No entanto, a imagem prolonga o discurso feito 12 anos antes: uma guardiã, à frente do sertão, fazendo o que a cidade tem de mais bonito. A jovem e seu bordado formam um cartão postal. ${ }^{18} \mathrm{~A}$ imagem do convite certamente corresponde aos discursos oficiais, sejam os do Estado, da Igreja ou das associações, mas talvez não inclua a perspectiva de outras bordadeiras.

Os bordados de Caicó recortam a esfera pública da festa, em seus mais variados sentidos, ainda que não sejam explicitamente militantes. São eles que tiram as bordadeiras de suas casas e as colocam em situação de ação política. Mesmo quando a política é o tema, como na abertura da Famuse, e apenas a representante da associação tenha espaço para uma fala pública, as narrativas dissidentes brotam e invertem a lógica proposta, afinal, até a performance pensada - e encomendada - como propaganda se realiza de forma crítica, revelando conhecimento sobre o jogo político, a cidade e as bordadeiras.

Como personagem desta celebração e da cidade, vale destacar que o bordado revela uma lógica específica. Como um bem de consumo prestigioso, corresponde à forma de ação simbólica, obtida pelo "papel que exerce em um sistema simbólico" e junto às expectativas coletivas (Gell 1998: 143). Appadurai (2008) observa que determinados bens têm uso retórico e social. São símbolos materializados que envolvem restrição, complexidade de aquisição, virtuosidade semiótica, conhecimento especializado e um alto grau de associação entre a

18 A página da Famuse na rede social Facebook apresenta a jovem Gerusa como representante da "nova geração responsável por manter a tradição secular do bordar, ao modo seridoense, vivo e irretocável". Bordadeira desde os oito anos de idade, vive no sítio Quipaua, no município vizinho Jardim do Seridó, é filha de Maria da Guia, bordadeira muito respeitada por toda a comunidade. 


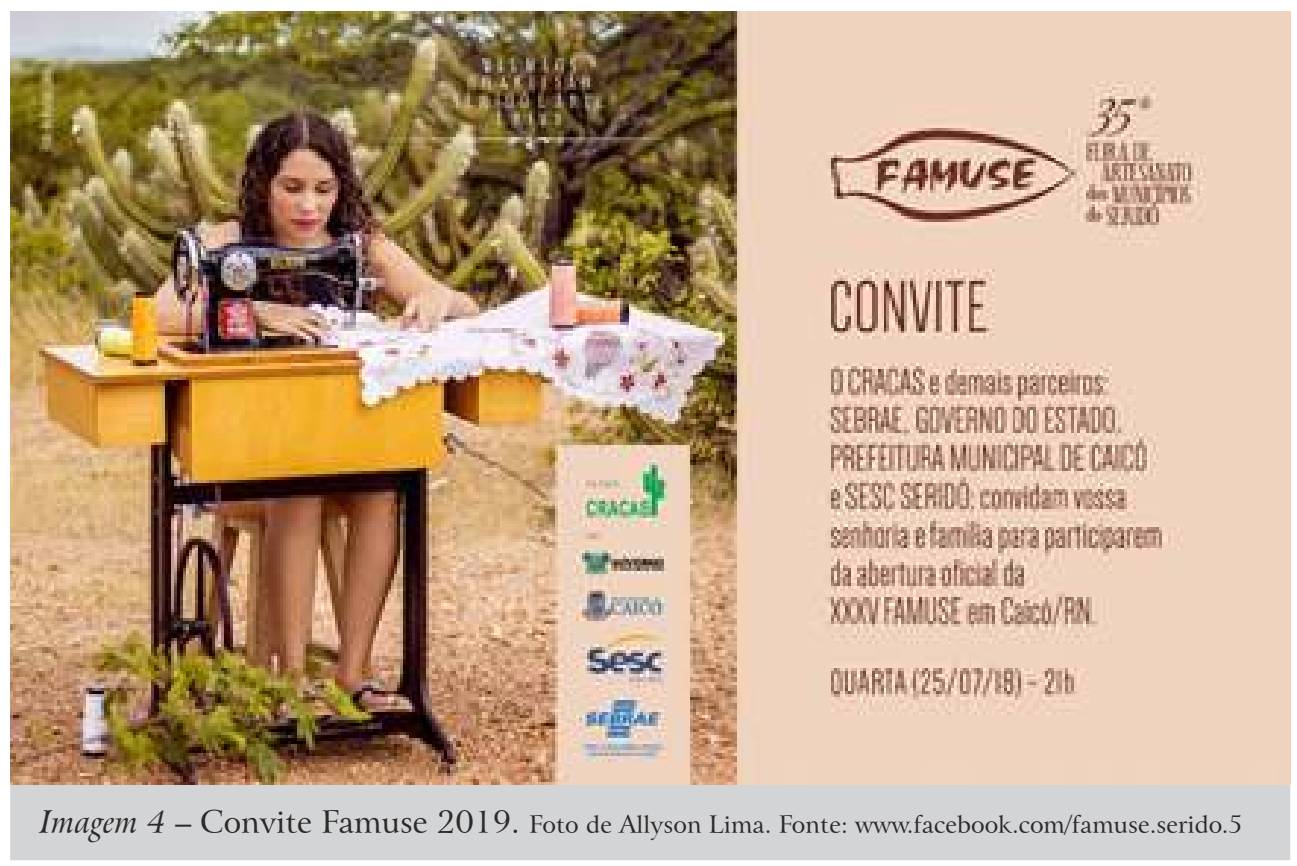

pessoa e a personalidade (Appadurai 2008: 57). Assim sendo, essas performances públicas de órgãos de fomento e de associações solidificam essa concepção simbólica sobre bordado.

Fazer política em Caicó significa para as boradeiras o engajamento no seu trabalho, o que vai desde o empenho na excelência da produção das peças, no ensino das técnicas e na participação na vida da cidade. Mas é também ao comunicar-se por meio dos bordados na criação e na circulação das peças que, de alguma forma, contam sobre a cidade. Esta é a forma pela qual os bordados permitem negociação e ampliação das redes. E mais, pela presença do corpo da bordadeira, a performance escapou ao script. Se, por um lado, o Estado e seus agentes fazem promessas consideradas vazias ou ineficazes, por outro, há um grupo que afirma que é o Estado quem depende das bordadeiras para que suas políticas de "identidade" se tornem aceitáveis. Além disso, se há um palco na festa que prioriza os discursos oficiais, outros palcos marginais são criados por elas mesmas para dar o recado que lhes é necessário.

\section{O uso do bordado na festa de Nossa Senhora da Purificação, em Santo Amaro, BA}

$\mathrm{Na}$ Bahia, durante dez dias, outra festa bicentenária leva seus bordados às ruas: a Festa de Nossa Senhora da Purificação. ${ }^{19}$ Vários eventos compõem a 
celebração, alternando perspectivas sagradas, incluindo o Candomblé - que introduz outras camadas de religiosidade e expressividade na festa -, e outras festividades profanas.

A semana que precede à procissão final, que encerra a festa com a missa na matriz, no dia 2 de fevereiro, recebe novenas no interior da igreja matriz da cidade de Santo Amaro, no Recôncavo Baiano. O soar dos sinos indica que a oração acabou, é o sinal de licença para que os festejos profanos se iniciem. Um palco montado na praça da Purificação recebe atrações artísticas regionais e shows em voga e, ao lado do palco, há o "bagacinho", uma espécie de feira gastronômica e local de encontro. Nesta praça alguns artesãos expõem seus produtos - raramente regionais -, há um parque de diversões e muitos vendedores ambulantes que movimentam as ruas ao redor. A cidade fica linda. Este lugar, marcado pelo estigma da escravidão, por inúmeros abandonos políticos, por uma constante crise econômica e pela quase ausência de empregos formais, se transforma com a alegria das crianças brincando, das conversas nas calçadas, no caminhar contínuo pelas ruas, sob gambiarras ${ }^{20}$ que recortam a cidade.

O ponto alto desta festa é a "lavagem da purificação", que ocorre no último domingo de janeiro, após a semana de novenas, precedendo à novena de encerramento. Este ápice dominical envolve uma multidão que vai às ruas da pequena cidade ver as baianas lavarem a escadaria da igreja matriz e ser abençoada com um banho de ervas e lavanda. Depois desta cerimônia, acontece uma espécie de carnaval de rua, animado pelas charangas, filarmônicas e seus instrumentos de sopro, tocando marchinhas carnavalescas e novas versões de músicas populares que fazem o povo dançar, brincar, tomar outros banhos pela cidade e, com alegria, purificarem-se e reiniciarem um novo ciclo.

Domingo é o dia em que o candomblé assume o aspecto sagrado da festa. Os preparativos se iniciam muito cedo. Em torno das seis da manhã, alguns terreiros da religião afro-brasileira já recebem suas baianas, preparam lavandas e quartinhas com ervas sacralizadas para jogar nas cabeças dos participantes da festa durante a cerimônia da lavagem. As baianas vestem saias rodadas, ricamente bordadas e com aplicações de renda. Colocam batas, panos da costa, joias de criola e turbantes sobre a cabeça ou em seus braços, e seguem com suas quartinhas. Dos terreiros vão para a casa de dona Canô, ${ }^{21}$ uma espécie de patrona da festa e quem por tantos anos a organizou. Naquele quintal, uma centena de baianas, alguns filhos e pais de santo e poucos convidados cantam, dançam, entoam seus orixás e alguns sambas de roda. Em torno das 11 horas, Maria Bethânia Veloso, filha de dona Canô, costuma iniciar um painosso. Após a reza, as baianas saem da casa e seguem até à matriz. O cortejo é

20 Fios de lâmpadas, colocados pelos espaços ocupados da festa.

21 Claudionor Viana Teles Veloso, falecida em 25 de dezembro de 2012, aos 105 anos. Mesmo após sua morte, é o seu quintal que segue recebendo este cortejo em festa. 


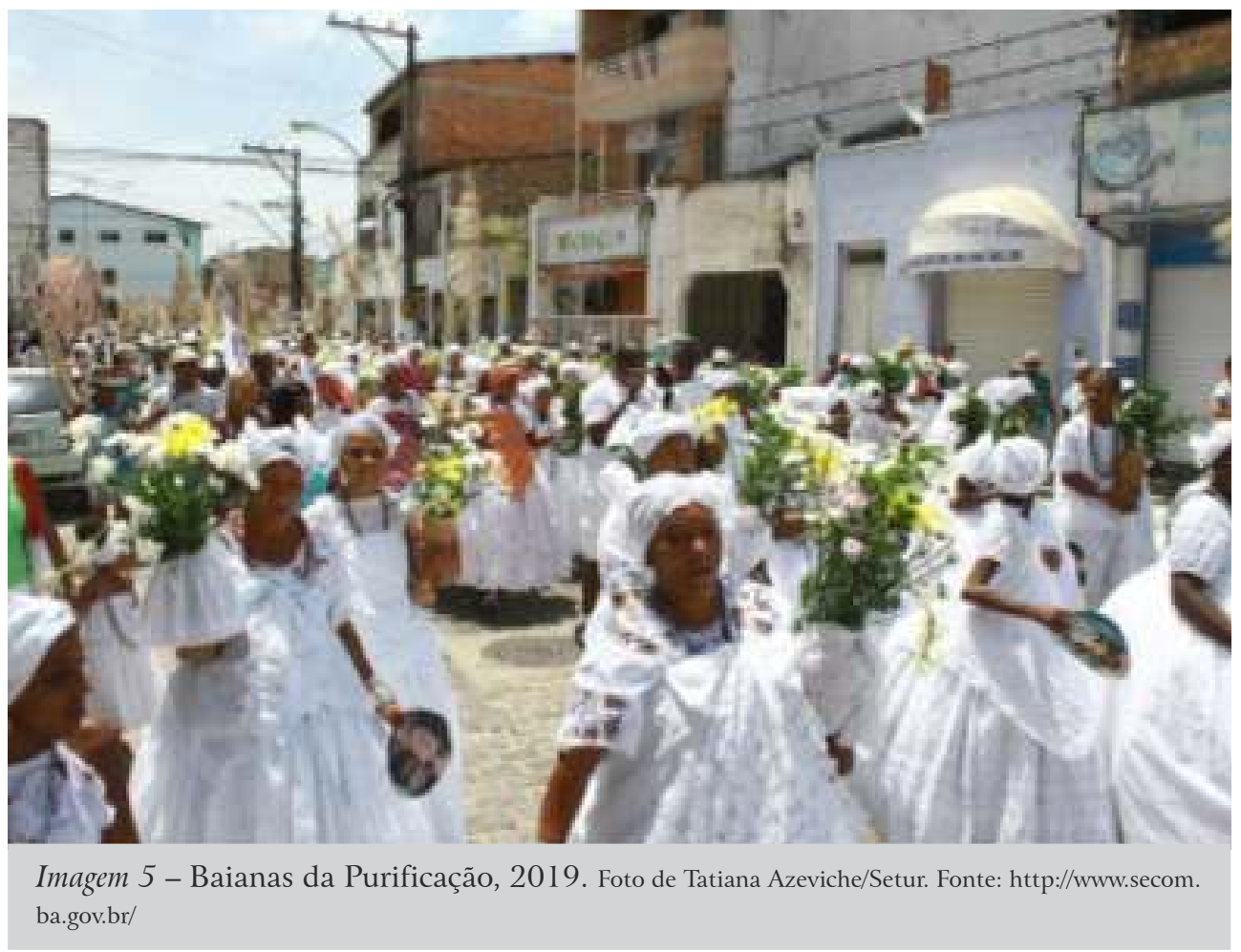

acompanhado por fogos, charangas, muita música, risos, abraços. É o sagrado em festa. Ao invés da contrição usual das procissões, ali é a alegria em sua plenitude. A celebração de se estar vivo. Como se o mundo parasse para se viver aquilo que fomos feitos para viver.

Se em Caicó vemos uma realidade geográfica descrita como árida, Santo Amaro, apesar de fértil, traz um tom de cansaço e de tristeza. Entretanto, assim como a terra potiguar, Santo Amaro se revela cheia de vida, criatividade, engenhosidade e posicionamento político. Nossa Senhora da Purificação guarda o culto católico à Virgem que remete à obediência à lei mosaica de purificar em águas a mulher após dar à luz, apresentando-se seus sacrifícios e o seu filho à comunidade espiritual. Na experiência sincrética da escravidão, Oxum, orixá das águas tranquilas - ou doces - traz a fertilidade, o amor e a beleza. Longe de apresentar o sincretismo como algo harmônico ou apaziguador, é interessante observar como se sobrepõem, coexistem e sobrevivem as cosmologias diante de uma realidade de opressão.

Domingo a cidade se torna no espaço do candomblé e de sua estética. Este é o dia em que os bordados assumem protagonismo pela profusão das roupas de santo. Em 2019, aconteceu uma situação que envolveu uma tensa relação entre terreiros e prefeitura, recortada por um uso específico do bordado 
richelieu. Destaco: esta festa é fundamental para a prefeitura, movimenta muito dinheiro pelo fluxo de turistas e apresenta a cidade como o embrião da cultura baiana.

O prefeito, à época, costumava repercutir discursos de eficácia, tecnicidade e independência. Valorizava a execução de obras públicas, foi um tanto polêmico devido aos atrasos no pagamento dos servidores municipais e da baixa consulta pública nas suas decisões. As parcerias religiosas andavam tensas e duas lideranças importantes, ligadas ao candomblé, confrontaram às vésperas da festa suas relações com a prefeitura. Apesar de uma gestão marcada por sérias denúncias de corrupção, o prefeito anterior mantinha uma favorável relação com a secretaria de cultura, bom diálogo com a comunidade religiosa e repetia pela cidade o slogan que o elegeu: "um homem de fé".

O motivo do conflito teve como estopim a remuneração das baianas que fazem a "lavagem". Anteriormente, o cachê era entregue aos pais de santo que organizavam o cortejo e que, por uma decisão unilateral da prefeitura, pagou o cachê diretamente às baianas, à revelia dos custos assumidos pelos terreiros. Pai Pote ${ }^{22}$ apesar de chateado com a situação, se arrumou lindamente, dirigiuse com suas baianas para a casa de dona Canô e, logo após a oração usual de Bethânia, foi o primeiro a sair, com braços abertos, em meio aos fogos e trompetes. Puxou o cortejo e, mesmo proibido pelo prefeito de falar em público, subiu ao palco, pôs-se ao lado do pároco ditando o que o religioso deveria dizer durante a cerimônia de acolhimento das baianas antes da lavagem. Quando o padre acabou "sua fala", pai Pote jogou o obi, ${ }^{23}$ pegou o microfone e começou a entoar um canto sagrado em Iorubá. Os microfones foram cortados.

Cerca de uma hora após o ocorrido, voltei à casa de dona Canô e lá estava pai Pote, como sempre alegre e falador. Comecei a brincar com a situação e sobre como ele se impôs naquele contexto. Afinal, havia invertido as lógicas da política, desobedecendo às regras que não correspondem ao espírito da festa. Em meio a esta conversa, comentei o quanto eu o achei bonito naquele dia e ele disse: "é, minha filha, eu vim de Logun-Edé".

Ele vestia uma bata com detalhados bordados em richelieu nas cores dourado, branco e vermelho. O desenho era tão recortado que apenas as cores se destacavam na rede formada pelos urdidos dos pontos cheio e caseado. Alternavam-se flores grandes, folhas e muitos arabescos. Pote vestia uma espécie de peitoril de conchas e no pescoço muitas guias e colares, um chamava a atenção: grandes peixes dourados. Este orixá é o protetor dos pescadores das águas doces, foi salvo por Orunmilá, quem o tirou das águas foi Yansã - após o jovem

22 José Raimundo Lima Santos, babalorixá responsável pelo Ilê Axé Oju Onirê.

23 Fruto sagrado que, na ocasião, foi mastigado pelo sacerdote e lançado à comunidade que ouvia os discursos. É usado nos jogos advinhatórios e numa variedade de rituais, como os de iniciação. 


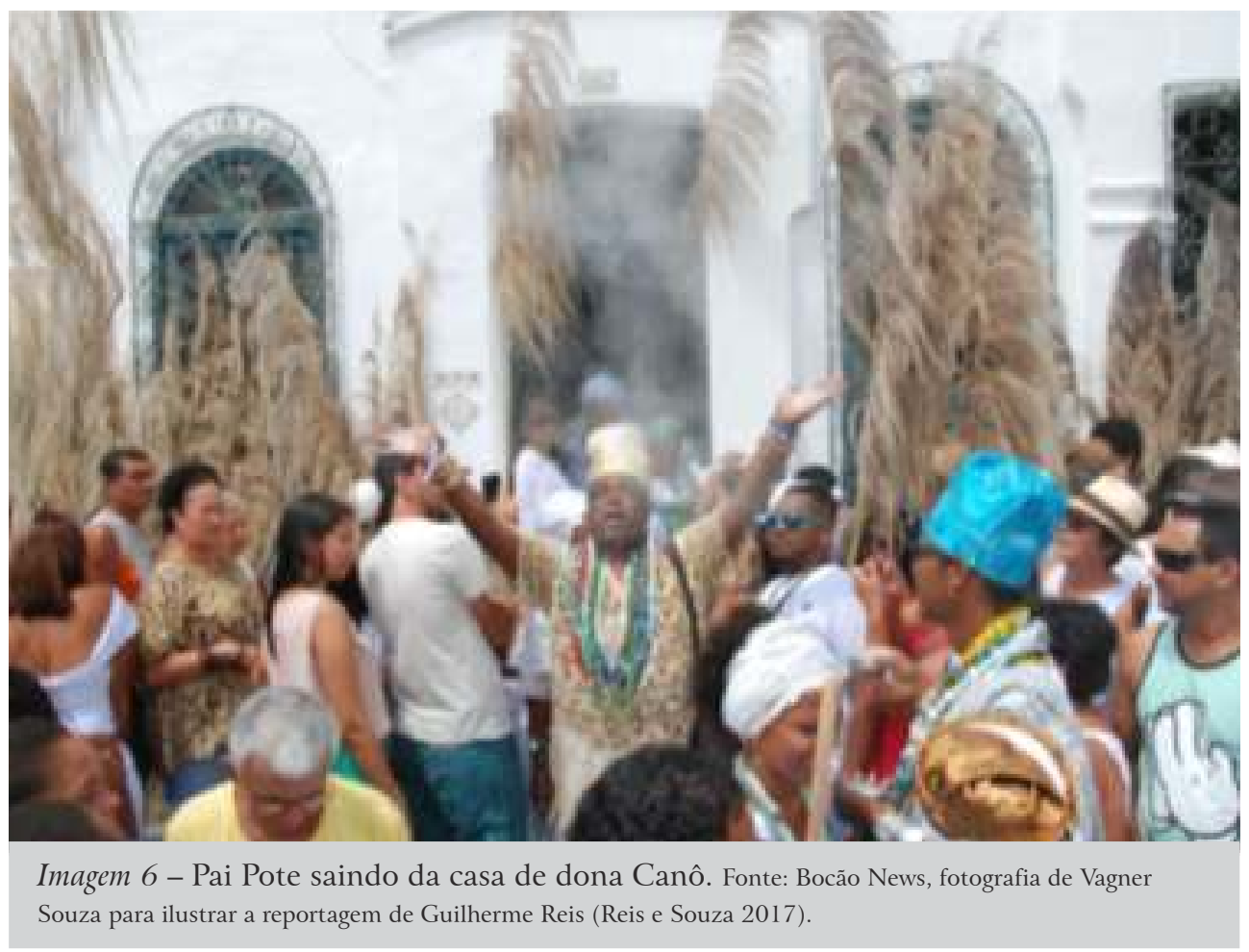

ter desprezado os conselhos maternos -, resgatando-o da tentativa de Obá o afogar como uma vingança a Oxum (Prandi 2000).

Como já aprendi que não há nada sem significado no candomblé, e ainda impactada com a festa e com a conversa com o pai de santo, pedi para que mãe Manuela de Ogum me contasse sobre este orixá ao qual o sacerdote se referiu:

“Logun-Edé é um orixá extremamente vaidoso, é um príncipe. É filho de Oxum e Oxóssi, presenteado por Ogum com cinto e punhal, para que soubesse se defender, é um guerreiro, herdeiro de Ogum. Quando se fala Edé, mostra que é caçador e quem o ensinou a caçar foi Oxóssi. Logun-Edé aprendeu desde pequeno a se defender. Tem intimidade com as águas, ensinado por sua mãe, e com as astúcias da caça, que aprendeu com seu pai. Carrega o ouro de Oxum e a esperteza de Oxóssi. As pessoas regidas por Logun-Edé são desconfiadas e nos chamam a atenção pela sua fisionomia, pelo rosto bonito e pelo seu olhar. O orixá é um príncipe. Talvez, por isso, ele goste de coisas boas. É apaixonado pelo ouro, pelos bordados. Quando se arruma com ouro, quer ser diferente. Apaixonou-se pela saia da mãe e, quando pequeno, só queria ficar embaixo da saia. Depois, resolveu ele mesmo usar saia porque com esta roupa ele se sentia muito mais orixá. Ele gosta de roupas de mulher 
e de homem, na verdade não é a roupa que o define ou, sequer, ele precise de definição. É um orixá inovador, diferente, bonito."

Naquela situação, quando não foi possível falar, pai Pote, considerando sua fé e ancorado na mitologia do candomblé, buscou nos bordados suntuosos de Logun-Edé e no seu modo imprevisível e juvenil de agir um caminho de astúcia e de beleza para dar o seu recado: aquela festa é, também, do povo de santo; o palco da Igreja é lugar do canto para o orixá e, por mais que se tente fazer calar um povo, haverá resistência. Assim, afirma-se que é possível inverter as lógicas da ordem e da política, desobedecendo pela roupa, pelo corpo e pela presença afrontosa. $\mathrm{O}$ amplo conceito de estética das religiões afro-brasileiras alteram e se adequam conforme a necessidade do

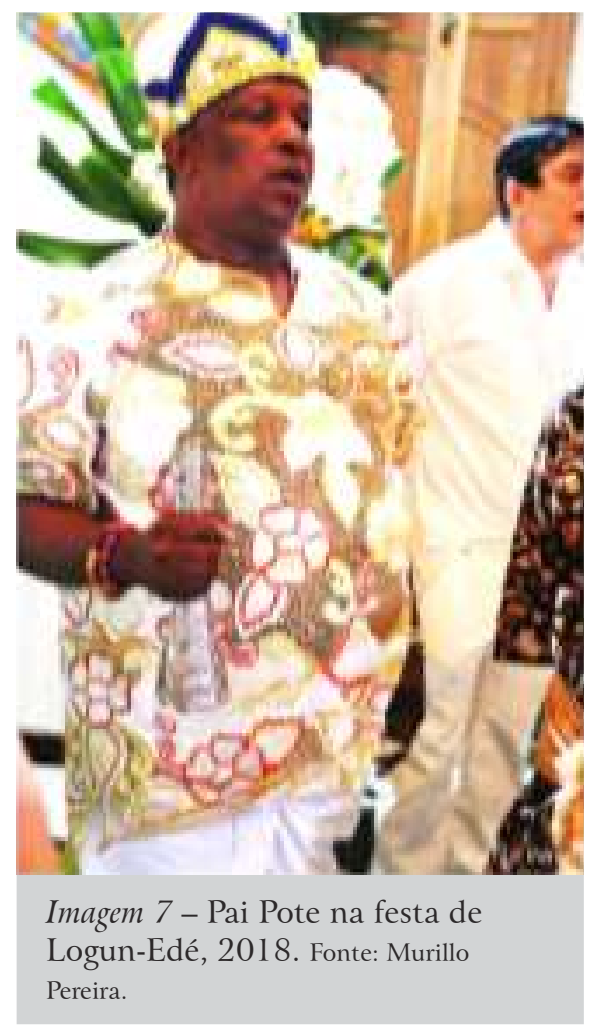
uso e da representação social. O sagrado pertence à criação e à invenção, assim como a vida pública. Não há como agir sem saber se defender, sem ter ousadia, sem ter criatividade e sem inovar. O recado foi dado.

É inevitável falar sobre a cidade de Santo Amaro sem considerar o seu papel fundamental no processo de colonização. Para mim, é também impossível falar sobre este local sem falar sobre a sua festa. A cidade encarna, ao mesmo tempo, o símbolo da dor e do sofrimento - e abandonos sucessivos - junto à força das manifestações culturais e das religiosas afro-brasileiras. Este mundo dos engenhos foi cunhado, por um lado, pelas grandes lavouras e casas grandes, comida farta e doces refinados, serestas reveladas em pianos bem tocados por educadas jovens (Freyre 1996 [1931]), por outro, uma multidão de homens e mulheres escravizados no cotidiano de trabalho e violência, lotando senzalas, criando possibilidades de parceria e de estratégias para a liberdade (Fraga Filho 2014), enquanto celebravam sua religião fazendo do corpo o seu tambor e as suas armas.

É interessante perceber que, mesmo não produzindo bordados como antes, não significa que eles tenham perdido a importância em Santo Amaro. Sigo buscando memórias e histórias de bordados na cidade. Nesta jornada, gavetas se abriram, lembranças de parentes que bordavam e muitas memórias sobre o 
ofício, técnicas e nomes de pontos permanecem, alguns exemplares de cadernos de amostra usados para ensinar as jovens me foram entregues, acompanhados de um lamento sobre o rigor a que eram submetidas as jovens, obrigadas a bordar a contragosto e com castigos. Sabendo disso, entendo que não bordar pode ser, também, um ato político. Contudo, mesmo quando o saber-fazer está guardado em uma gaveta, a atualização, a circulação e o uso do bordado ainda trazem potência.

Com o candomblé, o richelieu escapou de ser uma coisa dos ricos, criando um novo sentido para o seu uso. Os bordados brancos, comuns nos trajes coloniais, passam a incluir outras cores, não apenas porque é bonito, mas porque as cores representam atributos dos orixás, tornando-se, deste modo, parte dos adereços da indumentária sagrada. Reverte-se a posse de um ofício e do gosto de certa elite branca e coloca-se o richelieu no centro de relações criadas no cadinho da opressão escravagista.

Seguindo este raciocínio, em nenhuma das duas festas apresentadas aqui as performances relacionadas aos bordados richelieu se deixaram capturar ou foram obedientes, ao contrário. Os distintos usos dos bordados acabaram por propor diálogos de cidadania. As coisas e os seus usos permitiram resistir às tentativas de opressão, de silêncio, de manipulação ou de apagamento. Os bordados se tornaram o mote para uma interação pública e para produzir denúncias. Além disso, por meio deles, foi possível expressar olhares diversos sobre o cotidiano, mas também sobre as festas. Por isso, revelaram-se intrinsecamente políticos.

\section{CONSIDERAÇÕES FINAIS}

O bordado traz uma dimensão estética ligada a um dimensão funcional que the é inerente: são bonitos e servem para algo. Bordar é uma tarefa que atravessa séculos e espaços, constituída por formas de transmissão do conhecimento e de disciplina do corpo, revela possibilidades de expressão, de trabalho e de fomento de vida. É parte da vida de muitas pessoas, seja na vida doméstica ou em situações públicas, desde o cotidiano ou em contexto de ruptura deste cotidiano. Rotina, esforço, trabalho, ocupação do tempo, descanso, militância, confronto, festejos, enfim, várias palavras com significados tão distintos e que nos apontam essa variedade também de significados, propósitos e gostos aos quais os bordados estão vinculados. É uma tarefa usualmente feminina e frequentemente realizada em âmbito doméstico, mas aqui o bordado surgiu em circuitos públicos, sendo, inclusive, usado por homens para narrar histórias de outro ponto de vista.

Ao urdir vínculos, elaboram-se contextos de produção, vários fluxos de diáspora, modos de circulação, valores éticos que moldam o comportamento das bordadeiras em relação ao bordado, seja na forma de se produzir uma peça ou como se performar em uma festa. Parker (2010) assinala que, mesmo diante de 
tantos elementos que o bordado apresenta, ainda tratam essa cultura material como se fosse algo amador, doméstico, insignificante e supérfluo. Aqui tentamos cooperar para a interpretação dos bordados como objeto de ação política, rompendo com este senso comum.

Considerado um bordado elitista, vimos que o richelieu coloca a cidade de Caicó atenta aos bordados e às bordadeiras. Ali, o bordado é mais do que elemento decorativo, é o fio que expõe críticas diante das políticas públicas. E se os discursos tradicionais sugerem que bordadeiras precisam de ajuda, elas politizam os encontros dizendo que força e disciplina não lhes falta, que estão cientes de seu papel na comunidade e que não permitem a objetivação da cultura.

Em Santo Amaro, mesmo com os bordados distantes de suas bordadeiras, vimos a indumentária assumir uma narrativa potente, cuja mensagem torna explícita a defesa em expressar o que se pensa, o direito à cidade, a exercer a sua fé e a não aceitar a obrigação do silêncio. O bordado, ao invés de apaziguar o lar e filtrar o mundo para tornar a rotina mais calma (Carvalho 2008), aqui surge como afronta, inversão, ressignificação. É, portanto, uma ação política imprevisível e insubmissa.

\section{BIBLIOGRAFIA}

ADAMS, Jacqueline, 2013, Art against Dictatorship: Making and Exporting Arpilleras under Pinochet. Austin: University of Texas Press.

AMARAL, Rita De Cássia, 1998, "Sentidos da festa à brasileira”, Revista Travessia, maio-agosto: 5-8.

APPADURAI, Arjun, 2008, A Vida Social das Coisas: As Mercadorias sob Uma Perspectiva Cultural. Niterói: Editora da UFF.

ARAÚjO, Adrianna P. M., 2013, Bordados do Seridó: Uma Experiência Etnográfica com as Bordadeiras do Município de Caicó, RN. Natal: Universidade Federal do Rio Grande do Norte, dissertação de mestrado em Antropologia Social.

BRITO, Thaís, 2010, Bordados e Bordadeiras: Um Estudo sobre a Produção Artesanal de Bordados em Caicó, RN. São Paulo: Universidade de São Paulo, tese de doutorado em Antropologia Social.

BRITO, Thaís, 2016, "De artesã à empresária: uma reflexão sobre os discursos de formação empresarial das artesãs de linhas e agulhas”, in Rita de Cássia Alves e Cláudio Nascimento (orgs.), Formação Cultural: Sentidos Epistemológicos e Políticos. Cruz das Almas, Belo Horizonte: Editora UFRB e Fino Traço, 279-295.

BRITO, Thaís, 2019, "Narrativas e tecidos bordados", Cadernos de Arte e Antropologia, 8 (1).

Disponível em <http://journals.openedition.org/cadernosaa/1949> última consulta janeiro de 2022). 
CArvalho, Vânia C. de, 2008, Gênero e Artefato: O Sistema Doméstico na Perspectiva da Cultura Material - São Paulo, 1980-1920. São Paulo: EdUSP/FAPESP.

CASCUDO, Luís C., 2003, Rede de Dormir: Uma Pesquisa Etnográfica. São Paulo: Global Editora.

CAVIGNAC, Julie A., Muirakytan K. de MACEDO, Paula S. de BRITO, e Maria I. DANTAS, 2010, "O inventário da cultura do Seridó (RN) ou como dar conta do patrimônio imaterial de uma região”, Revista Memória em Rede, 3 (4): 48-84. Disponível em < www.ufpel. edu.br/ich/memoriaemrede $>$ (última consulta em janeiro de 2022).

CORBETT, Sarah, 2017, How to Be a Craftivist: The Art of Gentle Protest. Londres: Unbound. DURAND, Jean-Yves, 2006, "Bordar: masculino, feminino", in Aliança Artesanal (ed.), Reactivar Saberes, Reforçar Equilíbrios Locais. Vila Verde: Aliança Artesanal. Disponível em < http://hdl.handle.net/1822/5480 > (última consulta em janeiro de 2022).

FLOOD, Catherine, e Gavin GRINDON, 2014, Disobedient Objects. Londres: V\&A Publishing.

FRAGA FILHO, Walter, 2014, Encruzilhadas da Liberdade: Histórias de Escravos e Libertos na Bahia (1870-1910). Rio de Janeiro: Civilização Brasileira.

FREYRE, Gilberto, 1996 [1931], Casa Grande e Senzala. Rio de Janeiro, Edições Record.

GARDNER, Naomi, 2016, Embroidering Emancipation: Female Abolitionists and Material Culture in Britain and the USA, c.1780-1865. Surrey: Royal Holloway/University of London, tese de doutorado em Filosofia.

GELL, Alfred, 1998, Art and Agency: An Anthropological Theory. Oxford: Clarendon Press.

HOUCK, Carter, 2013, White Work: Techniques and 188 Designs (Dover, Embroidery, Needlepoint). North Chelmsford, MA: Courier Corporation.

IBGE - Instituto Brasileiro de Geografia e Estatística, 2012, Censo Brasileiro de 2010. Rio de Janeiro: IBGE.

IPHAN - Instituto do Patrimônio Histórico e Artístico, 2010, Dossiê Festa de Sant'Ana de Caicó. Disponível em < http://portal.iphan.gov.br/uploads/ckfinder/arquivos/Dossie_fest a_de_santana_caico.pdf $>$ (última consulta em janeiro de 2022).

JONES, Denise, 2020, "Articulating the threatened suffragette body: suffragette embroidered cloths worked in Holloway Prison, 1911-1912", Women's History Review, 29 (6), número especial. Disponível em < https://www.tandfonline.com/doi/abs/10.1080/096120 25.2020.1745403 > (última consulta em janeiro de 2022).

KLUT, Teresa, 2017, Casa de Bordados. Funchal: Serviço de Publicações.

LODY, Raul, 2019, Moda e História: As Indumentárias das Mulheres de Fé. São Paulo: Senac.

MAREnGO, Shanti N., 2016, Santo Amaro, BA: Um Lugar de Muitos Lugares. Salvador: Universidade Federal da Bahia, tese de doutorado em Geografia.

OSBORNE, Edward C., 1830, Zante, the Little Negro: (Addressed to the English Child). Birmingham: Printed for T. Groom.

PARKER, Rozsika, 2010, The Subversive Stitch: Embroidery and the Making of the Feminine. Londres: I. B. Tauris.

PEIXOTO, Fernanda A., 2020, “Os riscos da agulha”, Revista Trilhos, l (1): 75-91. Disponível em < https://revistatrilhos.com/home/index.php/trilhos/article/view/19> (última consulta em janeiro de 2022).

PRANDI, Reginaldo, 2000, Mitologia dos Orixás. São Paulo: Companhia das Letras.

RAMOS FILHO, Orlando, 2015, "Sant'Ana mestra: a mãe ancestral”, in Angela Gutierrez (org.), Museu de Sant’Ana. Belo Horizonte: Conceito Comunicação, 69-89. 
REIS, Guilherme, e Vagner SOUZA, 2017, "Festa da purificação: prefeito fala sobre 'retorno às tradições'”, Bocão News. Disponível em < https://www.bnews.com.br/noticias/cidades/ 165792-festa-da-purificacao-prefeito-fala-sobre-039retorno-as-tradicoes039.html > (última consulta em janeiro de 2022).

SCHWARCZ, Lilia M., 2018 [1998], As Barbas do Imperador: D. Pedro II, Um Monarca nos Trópicos. São Paulo: Companhia das Letras.

TORRES, Heloísa A., 2004 [1950], "Alguns aspectos da indumentária da crioula baiana", Cadernos Pagu. Disponível em < https://www.scielo.br/scielo.php?script=sci_arttext\&pi$\mathrm{d}=$ S0104-83332004000200015\#31b > (última consulta em janeiro de 2022).

WILDS, M., 1848, Zante the Negro. Birmingham: Graphic Arts Textiles Collection. Disponível em < https://graphicarts.princeton.edu/2014/02/27/anti-slavery-sampler > (última consulta em janeiro de 2022).

Receção da versão original / Original version

Receção da versão revista / Revised version

Aceitação / Accepted
$2020 / 10 / 22$

$2021 / 11 / 30$

$2022 / 01 / 21$ 